\title{
Screening for cystic fibrosis by examination of meconium
}

\author{
R. PROSSER, H. OWEN, F. BULL, B. PARRY, J. SMERKINICH, H. A. GOODWIN, and \\ J. DATHAN \\ From the Department of Paediatrics and Pathology, The Royal Gwent Hospital, Nevill Hall Hospital, \\ Monmouthshire, and City General Hospital, Stoke-on-Trent
}

\begin{abstract}
Prosser, R., Owen, H., Bull, F., Parry, B., Smerkinich, J., Goodwin, H. A., and Dathan, J. (1974). Archives of Disease in Childhood, 49, 597. Screening for cystic fibrosis by examination of meconium. The value of detecting albumin in meconium as a screening procedure for cystic fibrosis (CF) has been assessed on 34,228 samples in South Wales and North Staffordshire over a 4-year period; simultaneously, four methods of detecting albumin were evaluated. 12 cases of CF were detected, detection rate being $60 \%$. The incidence of the disease in the population screened was 1 in 1850, confirmed by clinical and other test procedures. Cases of CF without impairment of pancreatic function are likely to be missed by screening methods which depend on the presence of albumin in meconium.
\end{abstract}

Green, Clarke, and Shwachman (1958) showed that in comparison with the normal, the meconium in meconium ileus contains a large amount of protein, predominantly albumin. This excess albumin could also be detected in the apparently normallooking meconium of babies who are born affected by CF without meconium ileus (Green and Shwachman, 1968; Wiser and Beier, 1964). The albumin is probably derived from liquor amnii swallowed by the fetus and not digested because of impairment of the exocrine function of the pancreas (Pritchard 1965, 1966). Several authors have suggested that the presence of albumin in meconium had potential in screening for CF (Schutt and Isles, 1968; Green and Shwachman, 1968; Wiser and Beier, 1964).

A screening programme to record the presence of albumin in meconium of all newborns was initiated on 1 January 1970 in the Royal Gwent Hospital, and was extended to include all births in Monmouthshire, and later in East Glamorgan and North Staffordshire. The aim of the survey was to assess the value of detecting albumin in meconium as a screening test and to determine the most suitable test, method of recording results, and cost.

Methods

Part of the first or second specimen of meconium was Received 1 February 1974. collected into a sterile disposable container and sent to the laboratory suitably labelled. Conventional hospital transport was used, or for district deliveries and distant hospitals specimens were refrigerated at $4{ }^{\circ} \mathrm{C}$ and sent in weekly batches through the post to the laboratory.

The tests were performed in either the Paediatric or Pathology Departments of the Royal Gwent Hospital, Newport; the City General Hospital, Stoke-on-Trent; Nevill Hall Hospital, Abergavenny; East Glamorgan Hospital, Pontypridd; and Cardiff Maternity Hospital, Cardiff.

Four techniques were assessed, and frequently more than one type of test was used on a particular specimen of meconium (Table I). At the outset the trichloracetic acid (TCA) ring test (Green and Shwachman, 1968) was used. However, because of difficulty in recognizing the end point, it was soon abandoned in favour of the sulphosalicylic acid test (SSA), the predominant technique in the survey. All the specimens which were tested by Albustix and BM meconium test also had an SSA test done, and all positive cases of immunodiffusion also had an SSA test done.

SSA test. Approximately $1 \mathrm{~g}$ meconium was diluted 1 in 8 with saline and shaken mechanically for 30 minutes at 100 oscillations $/ \mathrm{min} ; 5 \mathrm{ml}$ of homogenate was poured into plastic tubes and centrifuged at 3000 r.p.m. for 15 minutes. Into duplicate $10 \times 75 \mathrm{~mm}$ plastic tubes 1.5 $\mathrm{ml}$ saline was dispensed, and to each tube $0.5 \mathrm{ml}$ of the meconium supernatant was added, giving an initial testing dilution of 1 in 32 . The dilution was thoroughly mixed with a vortex mixer and $0.2 \mathrm{ml}$ of $25 \%$ sulphosalicylic acid and added to one of each of the duplicate 
TABLE I

Number of specimens of meconium tested by each method

\begin{tabular}{c|c|cc}
\hline $\begin{array}{c}\text { Trichloracetic acid } \\
\text { (TCA) }\end{array}$ & $\begin{array}{c}\text { Sulphosalicylic acid } \\
\text { (SSA) }\end{array}$ & Immunodiffusion & Albustix \\
\hline 330 & 29,984 & 4535 & 20,087 \\
\hline
\end{tabular}

tubes and mixed; this tube was compared visually against the (blank) second tube.

In the absence of turbidity the result was recorded as being negative at 1 in 32 . Turbidity indicated a positive test for protein at 1 in 32 . In order to arrive at the final dilution which gave a positive result, a fresh series of doubling dilutions in duplicate were prepared from the 1 in 8 homogenate to a 1 in 512 dilution, and only if the test was positive in the latter dilution were further dilutions made, until a negative result was obtained.

Immunodiffusion. The technique was as reported by Bull, Gladwin, and Griffiths (1974) and Kollberg and Hellsing (1972).

Albustix (tetrabromophenol blue buffered to $p H$ 3 with citrate). One side of a test strip was moistened with diluted meconium (the supernatant as in SSA test). Any colour change in the test strip was noted and if considered positive was repeated on serial dilutions of the supernatant until a negative result was obtained.

BM test meconium. This was performed according to the directions provided by the manufacturer (Boehringer, Mannheim).

\section{Results}

There have been 40,801 births included in the survey area and 34,228 specimens of meconium have been tested, i.e. $84 \%$ of all possible births. 22 cases of CF have been diagnosed among the 40,801 births to date, an incidence of about 1 in 1850. 12 of these were detected by meconium screening. 8 were negative when the meconium was tested for albumin, and the remaining 2 were among the group from which no meconium was collected (Table II).

SSA test (Table III). A titre of $1 / 128$ or higher appeared to be significant for recognizing CF and was considered as a positive result. The 8 cases of CF missed by the test gave negative results at 1 in 8 dilution. 2 of these infants were sibs of known cases and were therefore anticipated as possible cases of CF. Their meconium was negative to SSA and Albustix and in one instance to immunodiffusion test.

Immunodiffusion test (Table IV). To date no case of CF has been detected in the survey by this

TABLE II

Overall results of meconium testing

\begin{tabular}{|c|c|c|c|c|c|}
\hline & Known cases of $\mathrm{CF}$ & $\begin{array}{c}\text { Meconium not } \\
\text { tested }\end{array}$ & $\begin{array}{l}\text { Detected by } \\
\text { examination of } \\
\text { meconium }\end{array}$ & $\begin{array}{l}\text { Not detected by } \\
\text { examination of } \\
\text { meconium }\end{array}$ & $\%$ detected by test \\
\hline $\begin{array}{l}\text { South Wales } \\
\text { North Staffordshire }\end{array}$ & $\begin{array}{r}16 \\
6\end{array}$ & $\begin{array}{l}2 \\
0\end{array}$ & $\begin{array}{l}9 * \\
3\end{array}$ & $\begin{array}{l}5 \\
3\end{array}$ & $\begin{array}{l}64 \\
50\end{array}$ \\
\hline Total & 22 & 2 & 12 & 8 & 60 \\
\hline
\end{tabular}

$\star 1$ case of meconium ileus.

TABLE III

Results of SSA test

\begin{tabular}{|c|c|c|c|c|c|c|c|c|c|c|c|c|}
\hline \multirow{2}{*}{$\begin{array}{l}\text { No. of } \\
\text { births }\end{array}$} & \multirow{2}{*}{$\begin{array}{l}\text { No. not } \\
\text { tested }\end{array}$} & \multicolumn{9}{|c|}{ Infants tested-serial dilutions } & \multicolumn{2}{|c|}{$\%$ of false positives } \\
\hline & & $\begin{array}{c}\text { Negative } \\
\text { or } \\
1 / 32\end{array}$ & $1 / 64$ & $1 / 128$ & $1 / 256$ & $1 / 512$ & $1 / 1024$ & $1 / 2048$ & $1 / 4096$ & $1 / 8192$ & $\begin{array}{l}\text { SSA } \\
\text { only }\end{array}$ & $\begin{array}{c}\text { SSA + } \\
\text { electrophoresis }\end{array}$ \\
\hline 35,688 & $\begin{array}{c}5702 \\
(2)\end{array}$ & $\begin{array}{l}26620 \\
(7)\end{array}$ & 508 & $\begin{array}{l}143 \\
(2)\end{array}$ & $\begin{array}{l}36 \\
(2)\end{array}$ & $\begin{array}{l}22 \\
(3)\end{array}$ & $\begin{array}{r}10 \\
(2)\end{array}$ & $\begin{array}{r}3 \\
(1)\end{array}$ & $\begin{array}{c}1 \\
(1)\end{array}$ & $\begin{array}{c}1 \\
(1)\end{array}$ & $0 \cdot 7$ & 0.02 \\
\hline
\end{tabular}

Numbers in parenthesis denote number of infants with $\mathrm{CF}$.

$\star$ Meconium with a titre of $\geqslant 1 / 128$ was subjected to electrophoresis. 
TABLE IV

Results of immunodiffusion test

\begin{tabular}{c|c|c|c|c|c|}
\hline No. of births & No. not tested & Negative $(<20 \mathrm{mg} / 100 \mathrm{ml})$ & Positive $(>20 \mathrm{mg} / 100 \mathrm{ml})$ \\
\hline 5111 & $576^{\star}$ & $4525^{\star}$ & 10 & 0.2 \\
\hline
\end{tabular}

^One infant with CF.

TABLE V

Results of Albustix test

\begin{tabular}{|c|c|c|c|c|c|c|c|c|c|c|c|}
\hline \multirow{2}{*}{$\begin{array}{l}\text { No. of } \\
\text { births }\end{array}$} & \multirow{2}{*}{$\begin{array}{c}\text { No. not } \\
\text { tested }\end{array}$} & \multicolumn{10}{|c|}{ Infants tested } \\
\hline & & Negative & $1 / 64$ & $1 / 128$ & $1 / 256$ & $1 / 512$ & $1 / 1024$ & $1 / 2048$ & $1 / 4096$ & $1 / 8192$ & $\begin{array}{c}\% \text { false } \\
\text { positives }\end{array}$ \\
\hline 20788 & 2250 & $\begin{array}{c}18304 \\
\text { (3) }\end{array}$ & 171 & $\begin{array}{l}33 \\
(1)\end{array}$ & $\begin{array}{l}18 \\
(2)\end{array}$ & $\begin{array}{l}10 \\
(1)\end{array}$ & 1 & $\begin{array}{c}1 \\
(1)\end{array}$ & - & 一 & $0 \cdot 3$ \\
\hline
\end{tabular}

Numbers in parentheses denote number of infants with CF.

test; 1 case gave a negative result, i.e. $<20 \mathrm{mg} / 100$ $\mathrm{ml}$ albumin in a $1 / 5$ meconium extract. It was also negative to SSA. 3 of the positives by this immunodiffusion technique were also positive for occult blood.

Albustix (Table V). The results were effectively the same as with the SSA test. Because of the green colour of the supernatant fluid (biliverdin), the interpretation of positive results was difficult. 5 cases of CF were detected using this technique, and 4 gave negative results. The 5 positive cases were also detected by the SSA test and the 4 negative cases were missed by the SSA test.

BM test (Table VI). 1 case of CF was detected and confirmed by this test. The number of false positives was small.

Electrophoresis (Table VII). :Protein electrophoresis is now performed routinely at the Royal Gwent Hospital on meconiums with a negative occult blood but with a positive SSA titre of $1 / 128$.
TABLE VI

Results of BM meconium test

\begin{tabular}{c|c|c|c}
\hline No. tested & No. negative & No. positive & $\begin{array}{c}\% \text { false } \\
\text { positives }\end{array}$ \\
\hline 2229 & 2216 & $13^{\star}$ & 0.6 \\
\hline
\end{tabular}

*One infant with $\mathrm{CF}$

This readily distinguishes between false and true positives; the latter are recognized by a dense albumin band. Only 8 of the 141 with false positive titres at $1 / 128$ showed albumin; in 6 of these the albumin was present in a small amount only. The 2 exceptions with a dense albumin band included a small premature infant weighing $1000 \mathrm{~g}$ who has subsequently thrived, and 1 normal infant who also gave repeatedly abnormal sweat chlorides in the first 2 weeks of life, with a gradual return to normal levels.

\section{Discussion}

Several tests have been used to assess the value of examining meconium for albumin as a screening test

TABLE VII

Results of electrophoresis

\begin{tabular}{|c|c|c|c|c|c|c|c|c|}
\hline & \multirow{2}{*}{$S S A \geqslant 1 / 128$} & \multicolumn{7}{|c|}{ Protein electrophoresis } \\
\hline & & $\begin{array}{c}\text { Albumin } \\
++\end{array}$ & $\underset{\text { trace }}{\text { Albumin }}$ & $\alpha_{1}$ & $\alpha_{2}$ & $\beta$ & $\delta$ & $\begin{array}{c}\text { Nil } \\
\text { significant }\end{array}$ \\
\hline $\begin{array}{l}\text { False positive } \\
\text { True positive } \\
\quad \text { (confirmed CF) }\end{array}$ & $\begin{array}{r}131 \\
8\end{array}$ & $\begin{array}{l}2 \\
8\end{array}$ & $\begin{array}{l}6 \\
-\end{array}$ & $\begin{array}{r}58 \\
8\end{array}$ & $\begin{array}{r}52 \\
6\end{array}$ & $\begin{array}{r}19 \\
2\end{array}$ & $\begin{array}{l}5 \\
2\end{array}$ & 42 \\
\hline
\end{tabular}


for CF. No one test appears to be more efficient than the other at detecting albumin. The end point is more difficult to recognize in the SSA test and with Albustix. Both these tests, together with the BM meconium test, because they are not albumin specific, gave slightly more false positives than the immunodiffusion test.

The number of false positives with the SSA test $(0 \cdot 7 \%)$, Albustix test $(0 \cdot 3 \%)$, and $\mathrm{BM}$ meconium test $(0.6 \%)$ can be reduced to a negligible number $(0.02 \%)$ if the positive reacting meconiums are subjected to electrophoresis, when false positives are excluded by the absence of an albumin band. The source of protein in false positives is not known, but the presence of blood is easily excluded by the occult blood test.

An SSA or Albustix titre of $1 / 128$ or higher is considered positive and suggestive of CF. Albustix can be used more directly as a ward test (Cain, Deall, and Noble, 1972), and Hobbs (1969) described a method for using Albustix which is both direct and, by providing its own control, simplifies the recognition of positives. The $\mathrm{BM}$ meconium test can be performed even by a relatively unskilled operator, the blue end point being easy to recognize. The time of the reading is not critical and the strip can be retained as a permanent record in the infant's notes. The immunodiffusion test gives a more definite end point and also the opportunity to detect the exact amount of protein present. It is sensitive, albumin specific, and there are fewer false positives $(0 \cdot 2 \%)$. All these tests were assessed at various times on known positives and were found to give more or less identical results.

False negatives, i.e. patients subsequently shown to have CF, have occurred with three of the tests and are likely in all four. No case of CF has been detected by one and missed by the other. Of the 6 cases not identified by this test, 3 were found to have normal excretion ( $<2 \mathrm{~g} /$ day). Fat excretion of the remaining 3 cases is not known, but one had a stool trypsin of 1 in 2000. This suggests that pancreatic function in these children is not severely disturbed, and would account for the negative meconium tests.

The detection rate in this survey, $60 \%$, is low compared to the $90 \%$ success described by Green and Shwachman (1968). However, their survey included only 196 infants over a 9-year period, all sibs of known cases of CF.

Approximately 10 to $15 \%$ of infants with CF have normal pancreatic function, and the remainder can be expected to give a positive meconium albumin test. Possibly the relatively low detection rate in this survey was due to the chance occurrence of an abnormally large number of infants with adequate pancreatic function. Green and Shwachman (1968) suggested that children with false positive results may represent heterozygotes, but this was not substantiated by us.

The protein appears stable, and transport of nonrefrigerated specimens through the post does not affect positive results. 6 specimens of meconium, which included known positives and false positives, were retested after 18 months and were found to give identical results with the SSA and Albustix tests and by electrophoresis.

Cost is important (Table VIII) and in this respect Albustix has a clear advantage if used as a ward test, but it is the least satisfactory of the four tests. When performed in the laboratory the cost is similar in the SSA and immunodiffusion tests and with Albustix, and the overall cost is only slightly increased if false positives ( 1 in 128 or greater) are subjected to electrophoresis. The BM meconium test is significantly more expensive, either as a laboratory or a ward test.

We conclude that the examination of meconium protein for CF is not an ideal screening test because of the large number of false negative results. However, because of its relative simplicity, low cost, absence of direct involvement of the parent and patient, and high yield of positive cases, its use on a wider scale is justified. Any future screening programme should also be used to assess the value of early prophylactic antibiotic therapy. On balance, there is little to choose between the tests, but the

TABLE VIII

Cost in pence $(p)$ of each test performed in the laboratory

\begin{tabular}{c|c|c|c|c|c|}
\hline SSA & SSA + electrophoresis & Immunodiffusion & Albustix \\
\hline $8 \cdot 35 \mathrm{p}$ & $8 \cdot 44 \mathrm{p}$ & $8 \cdot 85 \mathrm{p}$ & $\begin{array}{c}7 \cdot 96 \mathrm{p} \\
(0 \cdot 4 \mathrm{p})^{\star}\end{array}$ \\
\hline
\end{tabular}

* Cost if used as a ward test.

Note: Costs have been calculated on the basis that the test will be done in the laboratory by a technician and the results properly recorded Albustix (Schutt and Isles, 1968; Cain et al., 1972) and BM test are suitable for ward use and the cost could be further reduced if the material
is tested directly from the baby's napkin. 
immunodiffusion, or the SSA test plus electrophoresis, are the most satisfactory laboratory techniques, while the BM meconium test, though expensive, is preferred as a ward test because of its more easily recognized end point. We advocate that all specimens should be tested in a laboratory where quality control can be assured and results properly recorded and notified by an appropriate secretariat.

We express our appreciation to Drs. G. S. Andrews, J. N. Dearnaley, John Brown, and P. Bray; and to Mr. R. Christopher-Prosser, Mrs. L. Mercy, Mrs. S. Knight, Mrs. G. Fisher, the paediatricians and Medical Officers of Health in the regions for their help and co-operation; and to the numerous midwives responsible for collecting the specimens to make this survey possible. This work has been supported by the Cystic Fibrosis Research Trust and the Welsh Hospital Board.

\section{REFERENCES}

Bull, F. E., Gladwin, D. E. O., and Griffiths, A. D. (1974). Immunochemical method for detection of albumin in human meconium. Archives of Disease in Childhood, 49, 602.
Cain, A. R. R., Deall, A. M., and Noble, T. C. (1972). Screening for cystic fibrosis by testing meconium for albumin. Archives of Disease in Childhood, 47, 131.

Green, M. N., Clarke, J. T., and Shwachman, H. (1958). Studies in cystic fibrosis of the pancreas: protein pattern in meconium ileus. Pediatrics, 21, 635.

Green, M. N., and Shwachman, H. (1968). Presumptive tests for cystic fibrosis based on serum protein in meconium. Pediatrics, 41, 989.

Hobbs, J. R. (1969). First meconium in the detection of fibrocystic disease of the pancreas. Protides of the Biological Fluids, 16, 517.

Kollberg, H., and Hellsing, K. (1972). Screening for cystic fibrosis. Archives of Disease in Childhood, 47, 836.

Pritchard, J. A. (1965). Deglutition by normal and anencephalic fetuses. Obstetrics and Gynaecology, 25, 289.

Pritchard, J. A. (1966). Fetal swallowing and amniotic fluid volume. Obstetrics and Gynaecology, 28, 606.

Schutt, W. H., and Isles, T. E. (1968). Protein in meconium from meconium ileus. Archives of Disease in Childhood, 43, 178.

Wiser, W. C., and Beier, F. R. (1964). Albumin in the meconium of infants with cystic fibrosis. A preliminary report. Pediatrics, $33,115$.

Correspondence to Dr. R. Prosser, Department of Paediatrics, Royal Gwent Hospital, Gwent NPT 2UB, Wales. 